Hechiche / The Levantine Review Volume 2 Number 2 (Winter 2013)

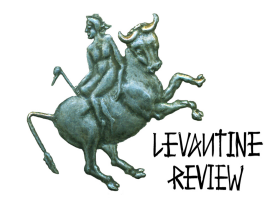

\title{
THE JASMINE REVOLUTION BETWEEN SECULARISM AND ISLAMIC FUNDAMENTALISM; THE CASE OF TUNISIA AND THE ISRAELI-PALESTINIAN CONFLICT
}

\author{
Abdelwahab Hechiche*
}

\begin{abstract}
The central impetus of this paper is the "un-Tunisian-like" hostile slogans emitted in early 2012 in honor of Hamas leader Ismail Hanya, during his official visit to Tunisia at that time. The slogans in question, among them "Kill the Jews!" were protested by many Tunisians, and were widely denounced as an insult to the Jews of the world, but more importantly perhaps, they were decried as affront to Tunisia's own Jewish children. Upon his historic return from exile and from jail, one of Bourguiba's first acts was to visit the poor Jewish quarter of "Hafsya," a gesture that reminded us of the Bey of Tunis, and the King of Morocco, both of whom, courageously, during WWII, declared their total and unconditional commitment to the defense and protection of their Jewish subjects. Integrating its tolerant "Mediterranean" past, and charting a post-Jasmine Revolution future is one of the major challenges facing the Tunisia of today.
\end{abstract}

\section{INTRODUCTION}

The implied idea of "waves" initiated by the Jasmine Revolution in Tunisia-the instigator of what would later become known colloquially as the "Arab Spring" - is all the more pertinent as social observers began associating it with a "tsunami," or an unexpected change of dictatorial and oppressive regimes in the Maghreb and the Middle East. Europe seems to have responded to the preceding with short terms interests, in the name of a conservative realpolitik, without a real strategic vision, nor a reasonable concern for the will of the peoples who achieved that early change in the Maghreb. Some scholars underlined the fact that the difficulty confronting Western powers was the dichotomy in their analysis between democratic values and differentiated political frameworks. "By repeating [...] 'It's better to have Ben Ali and Mubarak than the Muslim Brothers', many leaders and observers entrapped themselves in a contradiction: Those who defended human rights [...,] concomitantly were supporting Arab dictators under the pretext of combating terrorism." 1

${ }^{1}$ Frederic Toulon, Linda Prince, Bernard Terrany, and Negar Youssefian, "Mutations du Monde Arabe," Maghreb-Machrek, (No. 209, Automne 2011,) 97. 


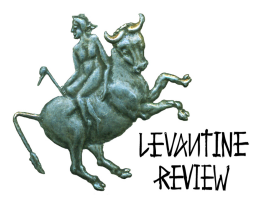

The choice of Tunisia as a case study may be justified by the fact that, after a brief moment of appearing as a potential model for the rest of the Arab world, Tunisia took a drastic and regressive orientation toward extremist fundamentalist Islamism. The most dramatic sign of such a dramatic resurgent ideology was marked by a new contender to Ennahda-the so-called "moderate" local Islamist party. The new challenger in question was Salafism. This new extremist Islamist ideology shocked the Tunisian people in their majority and caused vivid public and private debates about the essence of Tunisian identity: Although proud of their Arab-Islamic heritage, Tunisians have always been conscious of the specificity of their "Tunisianity." Although early violent acts committed by Salafist were quickly condemned by Rached Ghannouchi, the leader of Ennahda, he never succeeded in putting an end to them. Furthermore, Ghannouchi and his partners appeared to have not even tried hard enough to prevent more violence unleashed within the Manouba University against journalists and women. Salafist violence was to be suspected of two political assassinations, their victims being opposition members: Hosni Belaid, and Mohamed Brahmi. Naturally, some observers had enough reason to suspect that Rached Ghannouchi's timorous response may be hiding a double Machiavellian scheme: Let the Tunisian people see how moderate Ennahda is, and show some tacit understanding with Salafists for the next elections. In such a context, Tunisians had to assess the real chances for a genuine "democratization" because this new extremism, alien to Tunisia's political culture, was not different from what was reported by the American press regarding the ongoing efforts of the Muslim Brothers to eradicate any civil right for women, depriving them even of the right of complaint, not to mention any legal recourse against sexual violence, on the pretext that "marital rape" was a Western notion. ${ }^{2}$

The central impetus of this paper was the "un-Tunisian-like" hostile slogans emitted in early 2012 in honor of Hamas leader Ismail Hanya, then on an official visit to Tunisia. The slogans in question, among them "Kill the Jews!" were protested by many Tunisians and were denounced as an insult to Jews of the world. But more importantly perhaps, they were decried as an affront to Tunisia's own Jewish children. Upon his historic return from exile and from jail, one of Bourguiba's first acts was to visit the poor Jewish quarter of "Hafsya", a gesture that reminded us of the Bey of Tunis, and the King of Morocco, who, courageously, during WWII, declared their total and unconditional commitment to the defense and protection of their Jewish subjects. President F.D. Roosevelt wrote to both leaders in order to express his appreciation.

\section{RELIGION AND POLITICS IN NORTH AFRICA:}

${ }^{2}$ David Kirkpatrick and Mayy El Sheikh, "Muslim Brotherhood's Statement on Women Stirs Liberals' Fears," The New York Times, March 14, 2013. 


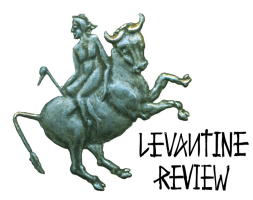

\section{THE EMERGENCE OF ISLAMISM IN TUNISIA}

\section{A Comparative Approach: The pre-Jasmine Revolution Era ${ }^{3}$}

The twilight of the twentieth century has experienced one of its strangest paradoxes: The rise of religious fanaticism in parallel with some of the greatest human achievements in terms of liberation from colonialism, and an end of authoritarianism. This paradox may even be more striking when one remembers that religion has played a major role in liberation theology. According to Richard Neuhass, shortly before passing away, André Malraux said that the twenty first century would be religious or it would not be at all. It was in that context that men and women of good will began to recommend an urgent and imperative dialogue between religions. Although Jewish-Christian dialogue had already been fruitful since Vatican II, Jewish-Muslim dialogue remained to this day embryonic. ${ }^{4}$ Paul Knitter explains how, in urging a pluralistic, liberative dialogue, he came to prefer a “Globally, Responsible, Correlational Dialogue Among Religions.” For him,

A correlational dialogue of religions affirms the plurality of religions, not because it is a fact of life. [...] A correlational model seeks to promote authentic, truly mutual dialogical relationships among the religious communities. [...] These are relationships in which persons speak honestly with each other and listen authentically. [...] Participants will be witness to what makes them distinct. [...] But, at the same time, they will be truly, courageously, open to the witness to truth that others make. This is mutual, back and forth co-relationship, of speaking and listening, teaching and learning, witnessing and being witnessed. ${ }^{5}$

According to Milton R. Kronviz, the terms "religion", and "religious" appear in the US Constitution but are not defined. This lack of definition is confirmed in a case involving the Mormon Church in 1878. Twelve years later, in another case involving again the Mormon Church, the court defined the term "religion" as having "reference to one's views of his

3 This part essentially borrowed from a paper presented in Germany, "Politik Mit Religion: Instrumente der Konflikts, Instrumente zur Mediation", Locum, 65/99

${ }^{4}$ I am grateful and I give full credit to the leaders of the US Interreligious Committee for Peace in the Middle East for having invited me to join the First US Jewish-Christian-Muslim Delegation for Peace in the Middle East in 1992 with the full support of former President Jimmy Carter.

5 Paul F. Knitter, One Earth, Many Religions: Multi Faith Dialogue \& Global Responsibility, Preface by Hans Kung ORBIS Books, (New York, 1995,) 15-16, quoted by A. Hechiche, What Jews Should Know About Islam and Muslims: Remembering A Common Heritage, (Paris: Éditions Publisud, 2002,) x-xi. 


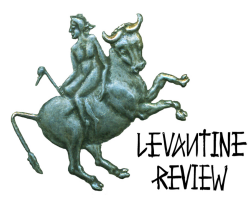

relations to his creator..."6 Two years later, the court found itself compelled to go a step further, and, practically identified religion with Christianity, saying "we are a religious people," and that "this is a Christian nation."7 These introductory remarks might be misleading if we did not add that the US Supreme Court never missed a chance to stress the separation of Church and State, the famous Jeffersonian wall. For instance, in 1961, the US Supreme Court considered the provision of Maryland Constitution that required a declaration of belief in God as a qualification for public office. Unanimously, the court maintained that such a qualification was an invasion of freedom of religion and a violation of the First Amendment. ${ }^{8}$ Speaking for the court, Justice Black said: "We repeat and again reaffirm that neither a state nor the Federal Government can constitutionally force a person to profess a belief or disbelief in any religion."9 To that effect, Samuel Krislov argued that "The fundamental difficulty in arriving at a stable balance is quite simply that state and religion have unstable boundaries." 10 More explicitly, Krislov adds:

Those religions that operate in states that fuse politics and moral force still have predominantly some separate structure for differing elements and subsequent rivalries. Those states that attempt to separate the two domains find demarcation less than complete. [...] God and Caesar do not normally conveniently limit their claims upon the individual involved. ${ }^{11}$

Such an ambiguity was made more pertinent when His Holiness Pope John Paul II visited Poland in 1983, "dramatically underscoring the message that what is a religious duty and need to one entity may emerge emphatically political to another." 12 The more recent explicit humility of His Holiness Pope Francis who, when asked about homosexuality, said "Who am I to judge?"

The question or the issue of the separation of state and religion becomes more acute for some religions, which are supposed to be political, intrinsically political. Muslim states fall within that category, all the more so as the essence of the idea of separation of state and

${ }^{6}$ Milton Kronvitz, The Problem of Constitutional Definition of Religion and State, Essays in Honor of Leo Pfeffer, edited by James E. Wood, (Waco, Texas: Baylor University Press, 1985,) and Davis vs. Beason, 133 US 333 (1890), 147.

${ }^{7}$ Kronvitz, 147.

${ }^{8}$ Samuel Krislov, "Alternatives to Separation of Church and State in countries outside the US," in Religion and State (Waco, TX: Baylor University Press, 1985,) 42.

${ }^{9}$ Krislov, 42.

10 Krislov, 422

11 Krislov, 422-23.

12 Krislov, 422-23.

ISSN: 2164-6678 


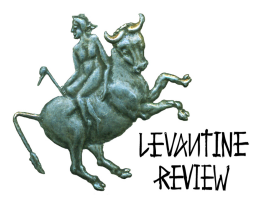

church has been generally perceived as an imported idea from the West. For Bernard Lewis, the three major monotheistic religions are significantly different in their relations with the state and their attitudes to political power. For him, comparatively speaking,

Judaism was associated with the State and was then disentangled from it. Its new encounters with the State at the present times raises problems that are still unresolved. Christianity, during the first formative centers of its existence, was separate from, and indeed antagonistic to the State with which it only later became involved. Islam, from the lifetime of its founder, was the state, and the identity of religion and government is undeniably stamped on the memories and awareness of the faithful from their own sacred writings, history, and experience. ${ }^{13}$

Generally speaking, the arguments given by Bernard Lewis explain how the idea of nonseparation of State and Religion evolved in Islamic thought. But they do not necessarily prove it either historically or contextually. In 1985, scholars could believe that with the exception of Turkey, "In almost all countries where its members constitute a majority, Islam retains much of its rigorous and tenacious hold on the State." 14 But, in actuality, the process of secularism (laicization in French) introduced by Kemal Ataturk as the sine qua non for modernization, was to be initiated by many Muslim leaders, before and after WWII, in Iran, Egypt, and in North Africa, specifically in Tunisia.

\section{Toward Change: From Bourguiba to Ben Ali}

"Human beings engage in conflict. [...] Equally, humans have sought, as long as there has been conflict, to handle the conflict effectively, by containing or reducing its negative consequences." 15 In international relations, historians, diplomats and international law specialists have agreed that the modern state was the result of the end of the Religious Wars (Treaties of Westphalia.) It may also be useful to say that the two Hague Conferences of 1899 and 1907 were the beginning of the humanization of warfare that further treaties and conventions, especially the 1949 Four Conventions confirmed. This is why Tidwell argues that "Parties and interveners must ask whether the necessary and sufficient

13 Bernard Lewis, "The Return of Islam," in Religion and Politics in the Middle East, edited by Michel Curtis (New York: West View Press, 1981,) 11-12, quoted by Krislov, p. 423, notes 3 and 4.

14 Kislov, 425.

${ }^{15}$ Allan C. Tidwell, Conflict Resolution? A Critical Assessment of Conflict Resolution, (London and New York; Pinter, 1998,) 1. This idea may be corroborated by the hesitant and cautious approach of the West regarding an eventual military intervention in Syria, especially after it has been confirmed that "chemical weapons have been used against innocent civilians on August 21, 2013. 


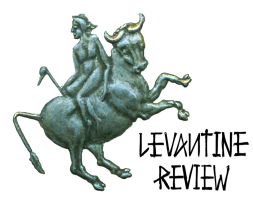

conditions exist, or to what degree they exist, to facilitate resolution," "these conditions being opportunity, capacity, and volition."16

In retrospect, any keen observer of the Maghreb could not deny the fact that the declining health of President Bourguiba, ${ }^{17}$ his clinging to power forever, and the corruption of members of his close inner circle including some members of his family, in particular, his Niece, Madame Saida Sassi, may have justified a need for "Change." Change was the trend in world affairs, and the Tunisian people wanted it. Members of the young generation who had not known the colonial period, went as far as to consider the Bourguiba era as a parenthesis in Tunisian history. In the case of the Maghreb, Michel Camau raised three issues regarding change in the relationship between State and Society:

1. The conciliation of a hypothetical economic liberalization with the centralized political order

2. The conciliation of a weakened efficiency of the regime with clientelist modalities of mobilization and consent.

3. The conciliation of new imperatives of legitimation with the foundations of the existing potential order. ${ }^{18}$

From this triple perspective, Michel Camau argued that

The issues of change are those of the conditions of the emergence of hypothetical formulae of regulations of conflict [...] with an interrogation about the pertinence of notions and concepts advanced by professional social theory, and/or suggested to the latter by official theory, i. e profane theory: Neo-patrimonialism, riots, civil society, democratization, democratic-transition... 19

What was important in the collective study on change in the Maghreb, as referred to by Michel Camau, was the emphasis on "civil society" which, like "religion," was perceived as "coming back." After asking whether civil society meant more state or less state, Camau

\footnotetext{
16 Tidwell, 4.
}

17 I witnessed it when he inaugurated the new Tunisian Embassy, during his last official visit to Washington in 1986, one year before the "medical-constitutional coup" orchestrated by his then Prime Minister, Zine Al-Abidine Ben Ali.

${ }^{18}$ Michel Camau, "Changements Politiques et Problématique du Changement," Annuaire de l'Afrique du Nord, (Paris: Éditions CNRS, Tome XXVII, 1989,) 9.

${ }_{19}$ Michel Camau, "Changements Politiques en Afrique du Nord-Transformations Sociales et Régulations des Conflits," Annuaire de l'Afrique du Nord, (Paris: Éditions CNRS, Tome XXVIII, 1989,) 5, note 15. 


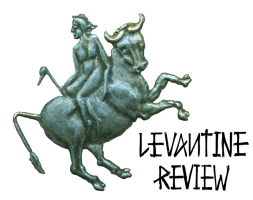

stressed a distinction between two dimensions of state, one material and one ethical: The bureaucratic apparatus which distinguishes itself from society in order to control it, and the pole of collective identification, which as a set of symbols, leads to mobilization of consent beyond the person of the ruler. In a more convincing way, Camau adds: "Between the apparatus and society [...] civil society designates a third component: A mediation through voluntary associations articulating the defense of special interests, and social conflicts." ${ }^{20}$ But, whereas Western Europe was re-discovering civil society, other regions like Central Europe and the Maghreb were re-appropriating it.

For the Tunisian sociologist, Abdelkader Zghal, this re-appropriation of the notion of civil society was "concomitant with two series of facts: The denunciation of the absolute state (Tout-État) and the emerging social disengagement of the State inspired by the nonorthodoxy of development."21 Thus, it becomes clear that the centrality of the tension between Religion, Politics, and the State is inseparable from the social, cultural, religious, and economic factors that affect all societies, in particular, societies which are still struggling with identity issues, especially with actual or mythical roots of their authenticity.

\section{BOURGHIBA AND THE PALESTINE QUESTION: BETWEEN PAN-ARABISM AND PRAGMATISM}

If the people are to advance toward great destinies, they must follow an enlightened leader, capable of triumphing over difficulties and of being equal to events. Everything then becomes possible, and the people can achieve miracles.

Habib Bourguiba ${ }^{22}$

\section{"La Politique des Etapes" The Policy of Stages}

Even before independence, Tunisia's political character was already shaped and nurtured by what became Bourguibism or "The Politics of Stages" (La Politique des Etapes). When WWII, by necessity or by choice, had to involve North Africa for the critical "Operation Torch," Bourguiba caught the opportunity to show his wisdom and lucidity to the emerging World Power, the USA: He resisted Hitler's offer, and sided with the Allied Forces led by the

${ }^{20}$ Camau, "Changements Politiques en Afrique," 10.

${ }^{21}$ Quoted by Camau, "Changements Politiques en Afrique," 11.

${ }^{22}$ Quoted by A. Hechiche, "World War II and the Globalization of Tunisia's Strategic Role in the Mediterranean," Actes du Colloque International sur l'Histoire de la Deuxieme Guerre Mondiale: La Campagne de Tunisie Novembre 1942-Mai 1943, Comité National Tunisien d'Histoire de la Deuxiéme Guerre Mondiale, 12-13-14 October, 1982, Tunis. 


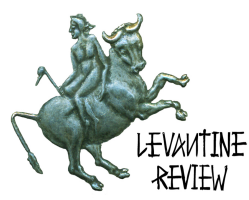

US and Great Britain. It is beyond any doubt that the history of twentieth century Tunisia is and will always be the history of Bourguiba as "the supreme combatant," and as the liberator of Tunisia from French colonialism, and above all perhaps, as the Arab-Muslim leader who liberated Tunisian women from cultural-religious shackles. ${ }^{23}$ Any critical analysis of Tunisia's struggle for independence, any specific phase of that struggle, must be constantly related to Bourguiba's own understanding of that particular moment and its environment at home and in world affairs. In one of his many famous speeches, he said:

To the extent to which these generations study national history, gain a precise idea of the suffering endured through the different periods of occupation, and realize that decadence and weakness attract invaders, they will continue to progress on the path we have traced, with enthusiasm, faith, and drive that enable us to raise this country from bondage. They will know how vital this work is, and will realize that it is the necessary extension of the struggle for liberation. ${ }^{24}$

Bourguiba had the prerequisite intelligence and sense of realism to use the authority of others or the force of unique circumstances to channel them into the direction of the national cause. ${ }^{25}$ An excellent illustration of his tactical and strategic skills is to be found in the alliance Bourguiba forged with the nationalist Bey of Tunis, Sidi Moncef Bey, who like the Sultan of Morocco, declared his unconditional protection of his Jewish subjects. ${ }^{26}$ On the other hand, Bourguiba, as a jurist, knew that the Bey of Tunis embodied whatever was left of Tunisia's sovereignty.

23 See the Code du Statut Personnel: Prohibition of polygamy/a Woman's Right to Choose Her husband/Equal Right for Education and Employment... But Bourguiba did not dare touch the question of inheritance in Islamic Law or Sharia. In "Killing the Arab Spring in the Craddle," Karima Bennoune, referring to the two political assassinations of 2013, writes: "But Ennahda itself bears much of the blame. It should be recognized, and condemned, for being the radical party that it is: a party that has created a climate for escalating fundamentalist violence that threatens the lives of liberal and secularist activists." The New York Times, July 30, 1023, p. A19.

${ }^{24}$ Habib Bourguiba, "This Land Shall Remain Forever Free," a speech following the complete evacuation of Bizerta, Tunis, October 15, 1963. Secretariat of State for Cultural Affairs Information, Tunis.

25 For instance, after accepting full autonomy from France, he managed to justify the necessity for accelerating the control of the process for full sovereignty to protect foreign embassies after right wing French demonstrations attacked the US Cultural Center. I was an eye witness of such events.

26 The US Library of Congress has copies of the letters sent to these two North African leaders from President F.D Roosevelt. 


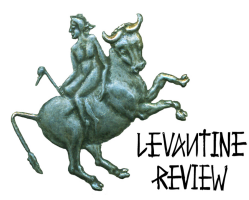

In his analysis of the colonial dialectic in North Africa, Clement H. Moore underlines the importance of the nationalist elite as being "The critical intervening variable." Very precisely, he explains how "Depending partly on the colonial situation, partly on their own sense of purpose, they [the nationalists] could be the motor of dialectic, of positive confrontation or the perpetrators of unreasoning violence, or the passive inheritors of the colonial order." 27 For the generation of Tunisians who may have witnessed Bourguiba's return from exile on a very hot June 1,1955, may also remember that one of his first major political acts was to visit the poor Jewish Quarter of Hafsya, to remind Tunisians of the cultural and religious specificity of their society, at a time when Arab-Israeli relations were marked by serious military confrontations. As a matter of fact, the Palestine Question and Pan-Arab propaganda did not prevent Bourguiba from appointing distinguished Jewish leaders to different ministerial cabinets. ${ }^{28}$ That uniqueness of Bourguiba's Tunisia was interpreted by Clement H. Moore as follows: "Only in it, did the dialectic unfold gradually, each moment or model of consciousness being the contribution of a distinct generation of leaders to an emerging political culture." 29 Yet, one can also assert that since the early 1930s, and for many years after independence, Allah, history, or both had decided that Bourguiba was to be, not only a link between two phases, but the motor and the consciousness of a nationalist movement, the dynamics of which had to be transcended from national to regional, and even to global dimensions. The Campaign of Tunisia during WWII was to be the opportunity and the challenge for Bourguiba's emergence as a world class Arab-African leader. Twenty years before John F. Kennedy, Habib Bourguiba already knew how "not to fear to negotiate," and "not to negotiate out of fear." In a rather moving, yet ambiguous, personal remembrance of the man who liberated Tunisia and made Tunisians regain a sense of pride and self-esteem, the man who, today, occupies the Presidential Palace of Carthage, thanks to the Jasmine Revolution, wrote very recently:

Even if he refused to move the country to democracy, and if he eliminated Salah Ben Youssef, my father's boss, my feelings toward Bourguiba remain complex. He was not a dictator, but an autocrat, and contrary to Ben Ali, he was not a thief. He is a man of

27 Clement H. Moore, Politics in North Africa: Algeria, Morocco, Tunisia, (Boston, MA: Little Brown Series in Comparative Politics, 1970,) 34-35.

${ }^{28}$ Albert Bessis and Andre Barouche, in Encyclopedia of Jews in the Islamic World, No. 303 and 393, http://www.docstoc.com/docs/115224460/List-of-Entries-Encyclopedia-ofJews-in-the-Isla...12/6/2013 ${ }^{29}$ Moore, Politics in North Africa, 37. 


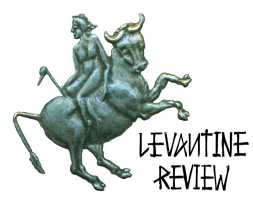

three fundamental leaps forward for Tunisia, which dictate to forgive him for his other acts. $^{30}$

\section{Ethno-Religious Politics: The Pressure of Pan-Arabism}

Zbigniew Brezinski was reasonably correct when he said that the longer a peaceful solution lingers, the more the inhabitants of the West Bank will be radicalized in their demands. This is normal, and it constitutes the natural history of any people aspiring to reach any form of political consciousness. Abraham Ashkenazi reduces the history of the twentieth century to two types of confrontation. One is of social nature, the other is essentially ethnic. Ashkenazi's analysis is very pertinent and useful for the comparative understanding of Zionist and Palestinian military movements. ${ }^{31}$ Ashkenazi sees a transfer of ethno-political particularism of the Balkans (before World War I) to the Middle East between World War I and World War II. It is interesting to notice that for Ashkenazi, at the beginning of the twentieth century, Palestinian nationalism was rather a consciousness of being "a southern Syrian." On the other hand, Ashkenazi considered Zionism as a non-Near Eastern phenomenon. Progressively, after the Nakba of the 1948 Arab-Israeli War, the Fatah leaders will progressively reject any assimilation of Pan-Arab ideology. Yet, willy-nilly, from its very beginning, Palestinian Resistance before and even after the creation of the Palestine Liberation Organization at the 1964 Cairo Summit, became intimately intertwined with Arab states politics. The simple fact that branches of the PLO would become vectors of conflicting Arab states ideologies, will also underline the subordination of the various Palestinian groups to various Arab states. "Often described as a threat against precarious states [... the] Palestinians were often recruited in large numbers to serve [Arab] regimes." 32 If indeed, Palestinians began to resist and then, even to confront Arab regimes (1970 in Jordan, 1975-1990 in in the Lebanese Civil War and Hafez Al-Asad's Syria,), Bourguiba could not be accused of being "plus royaliste que le Roi" for having dared to call the Palestinians to sit down and to negotiate with Israel, in his famous Jericho Speech of 1965, offering them the model of his successful experience based on the "Policy of the Stages." While the response to his invitation was utter condemnation from Palestinians and the promoters of Pan-Arabism, it was also regrettable, that some Israeli circles felt threatened by Bourguiba's ideas, seeing in them a scheme for the stage by stage implementation of the PLO Charter, i.e. the elimination of Israel. It would take the PLO

30 Moncef Marzouki, L'invention d'une démocratie: Les leçons de l'expérience de la Tunisie, (Paris: La Découverte, 2013,) 33.

${ }^{31}$ Quoted by A. Hechiche, L'Autodétermination Palestinienne Entre le Droit et la Force Face aux obstacles Américano-israéliens, Préface de Dominique Chevalier, (Paris: Éditions Publisud, 1991,) 110.

32 Rosemary Sayigh, Quoted by Helen Cobban, The Palestinian Liberation Organization: People, Power, and Politics, (New York: Cambridge University Press, 1984,) 197. 


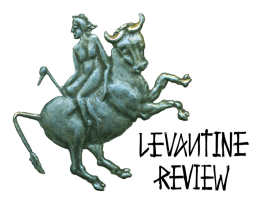

about thirty years to realize the wisdom and the lucidity of Bourguiba's prophetic suggestion. It was also Bourguiba's Tunisia which opened its doors to the PLO after being expelled from Lebanon after "Operation Peace in Galilee," when no other Arab state wanted to offer them refuge. It was also thanks to Tunisia-albeit under Ben Ali-that secret contacts between the PLO and Israel would open the path to the Oslo Agreements of September 13,1993, dramatically shown to the world from the White House and hosted by President Clinton. ${ }^{33}$

\section{THE JASMINE REVOLUTION; 2010-1011}

\section{The Roots}

Although President Zine Al-Abidine Ben Ali initiated his "Change" with freeing many political prisoners, and with saving the life Mr. Rached Ghannouchi, the founder of the Islamist Party, Ennahda, who had been condemned to death under President Bourguiba, he would emphasize the Islamist threat in order to justify his authoritarian rule. One must also take into account the fact that President Ben Ali did offer amnesty to Mr. Ghannouchi. But the latter elected to flee the country and to take refuge in the United Kingdom. That may have been a cause for sincere concern for the president who, on occasion, proclaimed that as long as he lived, the Islamists would never rule in Tunisia. The turning point was the rumor that Islamists were planning to bomb the Presidential Palace of Carthage.

Occasionally, some leaders of Ennahda would be released and then sent back to prison as it happened to Saddiq Chourou. ${ }^{34}$ The central political deterioration in Tunisia worsened from the last years of Bourguiba's autocratic rule to Ben Ali's increasingly dictatorial stifling of all expressions of dissent. ${ }^{35}$ The best mirror of such a loss of political and

33 Thanks to a visit to the Middle East with the first Jewish-Christian-Muslim American Delegation for Peace, supported by former President Jimmy Carter, and led by the US Interreligious Committee for Peace in the Middle East, in the fall of 1992, in March 1993, I had the privilege to be received by Chairman Yasser Arafat in Tunis. After asking him about the drastic change from the "maximalist" demands of the PLO Charter, and his new moderate position accepting a Two-States solution, he explained to me how he came to understand better the balance of power.

${ }^{34}$ Alexis Arieff, "Tunisia: Recent Developments and Policy," Congressional Research Quarterly Service, (RS 21666, January 18, 2011,) 5.

${ }^{35}$ I could share of fthe records the case of the infiltration of an American university by Palestinian Islamists and its impact on Tunisia because during a conference held on the campus of that university, the Tunisian scholars were attacked, and books and pamphlets criticizing Tunisia were displayed throughout all the proceedings. 


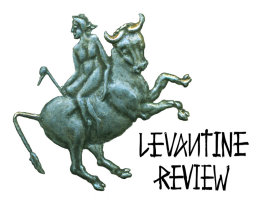

academic freedom is to be found in the weakening of the Tunisian League of Human Rights (LTHR.) Although charter items of the LRHR were taken almost verbatim from the 1948 Universal Declaration of Human Rights, Tunisian delegates quickly divided in two camps over two particularly controversial issues: Article 8, evolving from the UDHR's freedom of marriage, caused a critical debate with regard to Muslims women's right to marry nonMuslim men. "Liberals fought and won by a single vote language that would explicitly disallow marriage restrictions on the basis of race or religion, defeating a proposal for more vague language put forth by a coalition of 'nationalists' basing their arguments on the Arab-Muslim heritage of Tunisia."36

For a while the Arab Spring was compared with some of the greatest world revolutions (e.g. 1848, 1989) before scholars and analysts began to wonder whether the Arab Spring was a revolt or a revolution? Henry Laurens said "we historians are very strong for predicting the past. After a while, the events appear evident for us. [...] This reminds us of something essential: Any event has something fundamentally mysterious, in particular when it is about a revolution." 37 Whereas Sylvie Aprile saw some socio-economic similarities in 1848 France and 2011 Tunisia and Egypt, Henry Laurens agreed but said that such causes were not sufficient to explain the explosion. For him, it is imperative that "The peoples be motivated by the demand of dignity and freedom from fear."38 Laurens quoted an expression by one of the giants of French Romanticism, Lamartine, who spoke of the "revolution of disdain." For Laurens, Lamartine's "expression is pertinent for Ben Ali and for Mubarak as it was for Louis-Philippe: Their regimes were toppled because they no longer inspired fear but disdain, thus becoming illegitimate."39

Marwane ben Yahya encapsulated the phenomenon even better when he wrote that "the Arab world was coming out of a coma." 40 Less than one year before the self-immolation of Mr. Mohammed Bouazizi in Sidi Bouzid-a dramatic suicide full of symbolism which, apparently, became the catalyst of the Arab Spring in Tunisia and beyond North Africa-

36 Susan Waltz, "Tunisia's League and the Pursuit of Human Rights," The Maghreb Review, (Vol. 14. Nos. 3-4, 1989,) 220.

37 “Trois Historiens, Sylvie Aprile, Henry Laurens et Pierre Hassner, Analysent les Évènements en Cours dans le Monde Arabe et Décryptent les Similitudes et les Différences Entre Trois Grandes Vagues de Soulèvements Populaires: 1848, 1989, 2011," "Il Était une Fois La Révolution," Le Monde, Dimanche-Lundi 21 février, 2011.

${ }^{38}$ Henry Laurens, "Il Etait Une fois La Révolution."

${ }^{39}$ Ibid. See also, Benjamin Stora, Le 89 Arabe, Dialogue avec Edwy Plenel, Réflections sur les révolutions en cours, Stock, Paris 2011.

40 Marwane Ben Yahya, "Révolutions: Un Nouveau Monde Arabe," Jeune Afrique, (Paris: No. 2623-2624, April 17-30, 2011,) 30-31. 


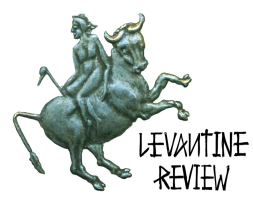

the arrest of a Tunisian journalist, Mr. Taoufic ben Brik, became a cause célèbre in France among journalists, members of the government, and in particular the Mayor of Paris, Mr. Delanoë, a native of Tunisia. ${ }^{41}$

\section{The Arab Spring and the West}

Western powers, in particular Europe, seem to have been taken by surprise. A meeting organized in Washington on October 27-28 by the European Union's Institute of Strategic Studies to prepare a common response to the Arab Spring revealed the surprise and worries among European and American leaders. This, in itself, could be sufficient to ignore those who, as we will see, spread the rumors that everything had been well planned from the outside. For instance, Philippe Gordon, a deputy to Hillary Clinton was reported to have said "The Arab movement began without us. We have neither chosen the place nor the timing, but we would be badly mistaken if we thought that we could control it." 42 Vali Nasr echoed the same sudden concerns. "What are American interests in the Middle east? How will we protect them as old regimes fall and new ones try to take shape? Can we influence outcomes? How should we prepare for the rise of Islamism?"43 As for the representative of the EU Foreign Minister Catherine Ashton, Pierre Vimont noted that the questions at hand are about the immediate future: "What goal should we follow? How do we deal with the different opposition movements, the emerging leaders? Are we well positioned to act collectively, Europeans and Americans?"44 Could all these statements from distinguished diplomats silence those who believe in a conspiracy? Eric Denécé, former intelligence affairs analyst, sounds categorical when he writes: "It is important to notice that in these two countries [Tunisia and Egypt] during the week preceding the troubles, the highest representatives of the armies went to Washington to get the green light for the toppling of

${ }^{41}$ Larbi Chouikha, Professeur à la Faculté de la manouba, Vincent Geisser, Chargé de Recherche à L'Institut de recherches et d'Etudes sur le Monde Musulman (IREMANS), Aixen-Provence, "La Fin d'un Tabou: Enjeux Autour de la succession d'un président, et dégradation du climat social," L'Année du Maghreb, (Paris: Éditions CNRS, 2010,) 388-392. 42 Sylvie Kauffmann, "Printemps arabe, Automne occidental," Le Monde, (Paris: DimancheLundi, 30-31 octobre 2011,) 8. This article contradicts a publication by a Tunisian weekly, Hebdo, 16-22 January 2012 entitled "La Main Américaine” (The American Hand) which literally expresses a conviction that "...The West, under the American locomotive, is the actual architect of this vast movement, prepared for a long time, and which was waiting for the first spark for an explosion and its propagation in the region..." 43 Vali Nasr, The Dispensable Nation: American Foreign Policy in Retreat, The Fading of the Arab Spring, (Doubleday, 2013,) 159. 44 Sylvie Kauffmann, "Printemps arabe, Automne occidental," 8. 


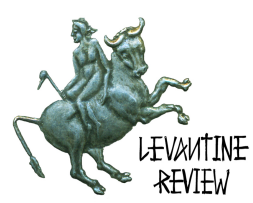

the leaders." 45 In addition, this author refers to Bernard Owen to say that "Since the 1970s, everything has been meticulously prepared. The international training of our activists includes what must be said, and the attitudes to exhibit in front of foreigners who are visitors. [...]In actuality, it is more a matter of moral formatting than formation [that is to say 'training'.]" 46

\section{THE JASMINE REVOLUTION; ITS IMPACT ON THE ISRAELI-PALESTINIAN PEACE PROCESS}

\section{Direct and Indirect Impact on Israeli Security}

It is obvious that the destabilization of the political regime of one of the most moderate Arab states toward the Arab-Israeli conflict must have been perceived if not as a threat, then at least as a cause, for serious concerns for Israeli security. One of the thorniest issues in public debates over the Arab-Israeli conflict pertains to the controversy between "Palestinian Rejectionnism" and "Land for Peace." 47 The Arab Spring and its growing and explicit religious orientation justify Israeli fears and those of Arabs and Muslims committed to a just and lasting Arab-Israeli peace. Whereas for many years, the Sinai Peninsula contributed to Egyptian-Israeli Peace as a natural buffer zone, the recent attacks by Islamist groups against Egyptian military and police posts in that area nullified the argument that "The Sinai Desert in the south buffers Israel from Egypt, the most powerful of its immediate neighbors." 48 This is also true of the eastern borders with Jordan. Should the Jordanian regime be replaced by an extremist Islamist one, Israel would certainly stiffen its security demands to extend its military presence as close as possible on that front. A very good and interesting point is made by two scholars when they look at Israel's security before and after the Arab Spring. In comparing the many major and limited conflicts opposing Israel and its Arab neighbors, Jeffrey S. Morton and Nicole Shortt underline a critical difference: The pre-Arab Spring conflicts were

45 Eric Denécé, “La Grande Illusion des 'Révolutions' Arabes," in La Face Cachée des Révolutions Arabes, (Paris: Centre de Recherche sur le Renseignement, Éditions Éllipses, 2012,) 13.

46 Bernard Owen, (Dir) La Société Civile, Un Cheval de Troie [Civil Society, a Trojan Horse,] (Paris: Studyrama, 2012,) 14.

47 Yosef Kupermann and Shalom Lipner, "The Problem is Palestrinian Rejectionnism, Why the PA must recognize a Jewish State," Foreign Affairs, (November-December 2011,) 2-9. 48 Jeffrey S. Morton and Nicole Shortt, "The Arab Spring: Implications for Israeli Security," Mediterranean Quarterly, (23:3, Summer 2012,) 35. 


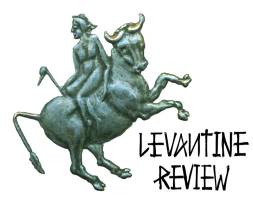

geographically contained. What is historic about the current Arab Spring is its tendency to connect and to overlap with similar uprisings taking place across international borders. Whereas as a result of social network technologies [...[ or as an accident of history, the simultaneous uprisings in the Arab world create a new dimension in the region and a significant threat to Israeli Security. ${ }^{49}$

On the other hand, the success of Islamist parties in the Maghreb and beyond, was not only a threat to Israel but also to Arab-Muslim states whose secularist leaders had adjusted and accepted "a geostrategic position as status quo states, preferring the current configuration of regional or international power over what could result if radical shifts in power were to occur."50

\section{Impact of the Arab Spring On Tunisia's Societal Fabric}

When the Arab Spring was still unfolding from Tunisia to Egypt, then back to Libya, some scholars wondered how "Middle East Studies" missed the Arab Spring? ${ }^{51}$ My own answer had already been presented during a Fellowship at the Harvard Center for Middle Eastern Studies, in 1989-1990. Another eloquent and timely answer came from Lisa Anderson. ${ }^{52}$ Already in the Mid 1990s, some observers saw the Arab world as a laboratory where political alliances and political changes were at the center the sociological debate. "The secularization of societies seemed to be replaced by a generalized return to clericalism: A universal phenomenon, made remarkable by the fusion of nationalism and religious dogma." 53 In trying to address the specificity of the emergence and evolution of Tunisia's Islamism, Abdellatif Hermessi raised a series of important questions, which remain vital in the today's debate about the future of the place of Islamic law or Sharia in the new constitution. ${ }^{54}$ Among the scholars who paid attention to the Islamic Revolution of Iran, Yvonne Haddad underlined the fact that one of Sayed Qutb's followers was Ali Sheriati who

\footnotetext{
${ }^{49}$ Morton and Shortt, 38-39

50 Morton and Shortt, 50.

51 Gregory Grause, "Why Middle East Studies Missed the Arab Spring? The Myth of Authoritarian Stability," Foreign Affairs, (July-August 2011,) 81-90.
}

52 Lisa Anderson, "Demystifying the Arab Spring: Parsing The Differences Between Tunisia, Egypt, and Libya," Foreign Affairs, (May-June 2011,) 2. Quoted by A. Hechiche, From the Arab Spring to the Islamist Spring, Jornata Tematica: The US and the MiddlEast, Insituto De Estudos Economicos e Internacionais, University of Sao Paulo, April 2012.

${ }^{53}$ Larry Fortis et Christine Passevant, Aires et Cultures Politiques au Moyen Orient, L'Homme et la Société, Etat Democratique ou Etat Confessionnel? Autour du Conflit Israel/Palestine, (Paris: L'Harmattan, No.114, 1994/4,) 3.

${ }^{54}$ Abdellatif Hermassi, L'Islamisme et l'Etat en Tunisie, L'Homme et La Société, (Paris: L'Hartman, No. 114, 1994/4,) 75. 


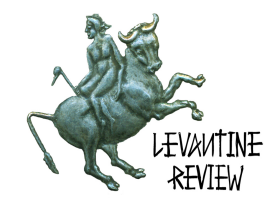

helped topple the Shah of Iran. Hichem Djait went even further in grasping the hidden objectives of the Iranian Revolution. "In the case of Iranian political Islam," he wrote,

we are facing a direct control of power [...] and this religious Islam is coming back not to reform itself, but to reform the global society and to impose itself to it. The recuperation of policies as action, and not only as thought, by the religious, [...] and the integration of the religious in an eminently political process, we have here without any doubt something representing a major phenomenon the novelty of which deserves our full attention. ${ }^{55}$

In the case of Tunisia, under Bourguiba,

when independence was declared, men of religion, "ulema and sheikhs," imams and scholars were passed over by the nationalists. [...] Thus, those with the legitimacy that derives from technological skill were able to unite with those whose legitimacy was political in nature. They created a modernist elite existing somewhat apart from the Islamic legacy. ${ }^{56}$

Under Ben Ali, the threat of Ennahda's Islamist orientation ${ }^{57}$ before and after the bloody Algerian civil war, led the government to progressively re-appropriate religion. ${ }^{58}$ Opening the Conference on Religion and Politics, Professor Mohammed Arkoun proposed two methodologies to approach this issue: "The relationship between Islam and Politics could be envisaged either in a recapitulative and descriptive perspective, or with the concern of thinking the various and difficult problems, that such a confrontation has produced from the origin..." 59

55 Hichem Djait, La Crise de la Culture Islamique, (Paris: Fayard, 2004,) 196.

56 J.C Vatin, "Revival in the Maghreb: Islam as an Alternative Political Language," in Islamic Resurgence in the Arab World, edited by Ali Dessouki, (Praeger, 1982,) 221.

57 The original name of the party was "Party of Islamic Tendencies. "

58 It was rather spectacular for those who lived in Tunisia, and for native Tunisians on professional visits to see the interruption of Radio/T.V programs being interrupted by official. State calls for prayers. Copies of the Holy Book, the Quran were conspicuously displayed on the desks of government officials. I saw one at the Ministry of Foreign Affairs, and the building of mosques, including the Zine Al-Abidine Mosque between Carthage and Sidi Dhrif...

${ }^{59}$ Mohanned Arkoun, "Religion and Politics", ACTS 15 ${ }^{\text {th }}$ International Conference on Sociology of Religion, (Paris: Centre National de la Recherche Scientifique (CNRS) and Presses Universitaires de France, 1980,) 11. 


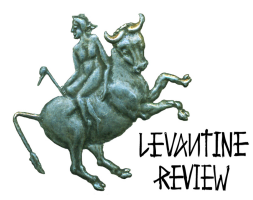

According to Ali Abderraziq, the question of the Caliphate had been a major concern in his studies and research for several years before publishing his work in 1925. It would be interesting to know if Kamal Ataturk knew about it. For Abderraziq, Caliphate was synonymous of Imamate. ${ }^{60}$ The implied understanding between Abderraziq and Ibn Khaldun is that power corrupts. By becoming monarchs, attached to their thrones and privileges, caliphs turned into sanguinary enemies of anyone who would dare resist them, even with the aid of scientific research. Abderraziq saw in this challenge the

origin of the pressures that kings exerted against the freedom of science, and the censorship they had used against teaching [and] education. [...] It is beyond any doubt that political science, in so far as it looks for the nature, the particularity, and the structure of the different types of government, is one of the most dangerous disciplines. Therefore, it is natural that kings become its worst enemies, and that they use all available means to deter people from pursuing it. ${ }^{61}$

More directly , and more audaciously, Abderraziq adds: "Prophet Mohammed was nothing but an apostle of God, like his brothers who preceded him in that function; he was neither a king, nor a founder of empire." 62

It is also fair to admit that Islam is not the only monotheistic religion to face the problematique of the tension between religion and state. In the 1990s, a simple but theologically and ideologically explosive question "Who is a Jew?" divided the Knesset and threatened millions of American Jews until it was tabled. Today, we have a similar situation when one could ask "who is a Muslim?" in particular since Sayed Qutb coined the concept of "Neo-Jahiliyya," meaning that all existing secular Arab-Muslim states represented a new version of paganism. Is it the reason why Herbert Spencer viewed the state as always preserving some of the characteristics of the church, even at the end of a long process of secularization. "It is the nature of power to maintain, either an overt or a masked form, of

${ }^{60}$ Ali Abderraziq, after defining the term Khilafa-the replacement of someone for different reasons, he borrows two definitions: 1 . From Al-Badawi "The Imamate is the interim of the Prophet held by a person with the objective of ensuring that the religious law (Shari'a) be respected, and to defend the integrity of the faith..2. From Ibn Khaldun: The caliphate was to be the leadership of the Community according to the Shari'a, for the sake of the Community's salvation and its temporal interests, because the affairs of this world are linked with those of the hereafter. L'Islam et les Fondements du Pouvoir, (Paris: La Découverte /ccdej, series Islam et Société, 1994.)

${ }^{61}$ Abderraziq, 80.

62 Abderraziq, 114-115, quoted by A. Hechiche, What Jews Should Know About Islam and Muslims: Remembering A Common Heritage, (Paris: Publisud, 2005,) 181. 


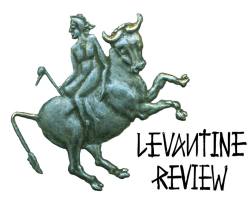

political religion..."63 In the same context, Marx also had to deal with the same problematique of State and Religion. For him, the two were similar in their essence, even when the state is separated from the church and in opposition to it. This essential similarity is due to the fact that the State is situated (or appears to be) beyond real life, in a sphere whose distance is reminiscent of that of the God of gods. ${ }^{64}$

\section{CONCLUSION}

When Georges Balandier referred to Luc de Heusch's formula that "Political Science derives from the comparative history of religions," it allowed him to complete his analysis with Durkheim's ideas about the relation between the Australian totem and the clan. "This relationship is essentially imbued with sacredness, for every society links its own order to an order beyond itself. Power is sacredness because every society affirms its desire for eternity..." 65 Like a synthesis of Balandier and Bassam Tibi's central idea about Islam as a "defensive culture," Professor Yadh Ben Achour's analysis was probably the most perceptive of the real dynamics of the under-current confrontation between secularism and Islamism in Tunisia. He argued that

It is precisely through a historical struggle against their "secular" adversaries that the legitimists constructed the normative Islamic system and gave it its coherence and its totality. [...] Therefore, it is correct to speak of "integrisme" [fundamentalism] when referring to religious movements which, wholeheartedly, defend the coherence of the system against the multiple forms of secularism. [...] The fundamentalist is one who pursues the combat of Ghazali [and] Ibn-Taymia for an integral Islam. [...] However, fundamentalism is not a mere militant ideology, but a type of thought, that the believer who totally adheres to the Islamic normative system, and who considers that any fissure in the coherence and in the unity of the system is a sign of heresy. ${ }^{66}$

By extending his analysis to the notion of "statism" as it appeared in Christian Europe in the sixteenth and seventeenth centuries, Yadh Ben Achour ${ }^{67}$ reminds us of Spinoza's view

63 Herbert Spencer, Principles of Sociology, referred to by George Balandier in Political Anthropology, translated from the French, by A.M Sheridan Smith, (Paris: Panthéon Books, 1970,) 100, quoted by A. Hechiche in What Jews Should Know About Islam, 212.

64 Hechiche, 212

65 Geroges Balandier, 100.

66 Yadh Ben Achour, Normes, Foi et Loi, en Particulier dans l'Islam, (Paris: Éditions Cérés, 1994,) 242-43.

${ }^{67}$ Yadh Ben Achour has occupied the critical post of President of the High Body for the Realization of the Objectives of the Revolution, of Political Reforms, the Democratic

ISSN: 2164-6678 


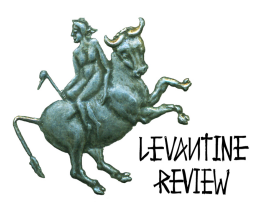

that "Religion acquires legal authority on the basis of the decree of those who are entitled to rule the state, that God's reign on men is established only by those who hold power."68 This leads Ben Achour to consider that Islam, religion of the State, becomes the credo of statism in the land of Islam. It does not mean at all the introduction of religion into politics, but rather its exit. ${ }^{69}$ More specifically, the confrontation that started under Bourguiba, and then, under Ben Ali, and which is continuing today after the October 23, 2011 legislative elections in Tunisia with a leading large number of votes for the so-called moderate Islamist party Ennahda, gives more authority to Yadh Ben Achour's pre-Arab Spring analysis of "statism" as "the submission of Religion to the State, [...] meaning that the believer, in his/her conviction remains perfectly free to determine his/her belief /disbelief. [...] In this area, neither the State, nor the Community may interfere. But this believer delegates to the State and only to it, public and collective religious manifestations. The believer keeps the religion of the law, but leaves political religion to the State."70

*Abdelwahab Hechiche is Professor of Government and International Affairs at the University of South Florida. He holds graduate and post-graduate degrees from the University of Paris, Sorbone, the Institute of Advanced international Relations of the Faculty of Law-Panthéon, and the École Pratique des Hautes Études. After being a French Fulbright Scholar from the University of Paris at Virginia Polytechnic Institute and the University of South Florida during the late 1960s, Hechiche was also a U.S. Fulbright Scholar in Algiers in 2006-2007.

Transition. See His Interview, "la Révolution, et Après?" [The Revolution, and Then What?] in Mondes, (Paris: Les Cahiers du Quai d'Orsay, No. 8, Automne 2011,) 27-32.

68 Baruch Spinoza, Traité de Théologie Politique, quoted by Y. Ben Achour, 258.

${ }^{69}$ Ben Achour, 259.

70 Ben Achour, 259. 